\title{
Parametric study of the thermal performance of a typical administrative building in the six thermal zones according to the RTCM, using TRNSYS
}

\author{
LAMRANI Abdelghafour ${ }^{1}$, SAFAR Said ${ }^{1}$, ROUGUI Mohamed ${ }^{1} *$ \\ 1 LGCE, Ecole Supérieure de Technologie Salé, Mohammed V University in Rabat 10 000, Morocco. \\ *Corresponding author. Email: rougui93@yahoo.fr
}

\begin{abstract}
In this work, we present a parametric study of a new administrative building, located in El-Ksar El Kebir region (Morocco). In order to have a building that complies with the RTCM in a technically and economically sound manner, we have carried out a number of interventions to insulate the components of the building, namely external walls, exposed roofs and openings. In this perspective, we have modelled the building envelope as a multi-zone building in TRNSYS and we have adopted an occupation scenario for this type of building. After determining the optimal insulation solutions, we simulated the administrative building in the five other thermal zones, to determine its feasibility in the latter.
\end{abstract}

\section{Introduction}

In recent years, the world experienced a terrible climate change, which everyone is talking about, so some countries have begun to apply different solutions to remedy this problem. The COP 21, in Paris, was closed by an international agreement on climate., setting as a target by 2100 the limitation of global warming between $1.5^{\circ} \mathrm{C}$ and $2^{\circ} \mathrm{C}$. witch was applied in the COP 22, in Marrakech, so Morocco has been working for a few years in a program that converges with global climate objectives, through the implementation of laws on energy efficiency and sustainable development, such as the Moroccan Building Regulation in Morocco RTCM, targeting the building.Morocco's energy consumption continues to rise rapidly each year.

Currently, the building sector accounts for $28 \%$ of final energy consumption, with a contribution of one third of total $\mathrm{CO} 2$ emissions, given that the potential for energy savings is estimated at $40 \%$ in this sector worldwide whole. A well thought-out construction design will always be more efficient and less costly since it is characterized by a long duration.

Energy consumption in Morocco continues to grow rapidly every year. Growth in demand for electricity exceeds the most accurate forecasts, with a growth rate of $7 \%$ to $8 \%$ in recent years. The country must import more than $97 \%$ of its energy needs (more than $16 \%$ of electricity was imported directly in 2014) with the construction sector as it is the largest consumer of energy, about $25 \%$ of The total energy used. Energy consumed in the residential sector represents $72 \%$ of the total energy absorbed by the building sector and the rest is devoted to higher education. Thus, the building sector represents the largest depository of savings; about $40 \%$ could be saved by combining several factors (effective lighting system, effective envelope and efficient electrical equipment).

In the perspective of the involvement of scientific research in development of technical solutions for energy efficiency, Benhamou et al [4] carried out a transient thermal simulation of a villa type house in the suburb of Marrakech in order to evaluate the effects of insulating external walls and roofs and integration of overhangs. The study concerns a new project and the results showed that the effect of insulating external walls has small beneficial effects on heating load while it increases the cooling load during summer, in this specific climate conditions. This works was conducted before the implementation of the RTCM; thus, they did not show if the integration of those solutions would reduce the energy demand for heating and cooling to meet the requirements values of the RTCM.

Although the issue of energy efficiency in existing buildings is very important given the scale of existing buildings in Morocco, the first version of the RTCM, which was published in the Official Journal of Morocco in November 2014 and becomes a mandatory regulation by November 2015 [5], it concerns only new projects. In this 
work, we tried to address those issues by modeling a new typical administrative building's envelope and providing solutions of insulation and integration of passive techniques (Overhangs, Double glazing, Insulating external walls and roofs) through nine cases in order to meet the requirements values of the Moroccan Thermal Regulation standards. The first case is the real building; the others correspond to the lack of one or several solutions. We modeled the building's envelope as a multi-zone building in TRNSYS and we adopted a scenario of occupation for this type of building.

\section{Nomenclature}

-RTCM : Règlement Thermique de Construction au Maroc;

- ADEREE : Agence National pour le Développement des Energies Renouvelables et de l'Efficacité Energétique ;

- DMN : Direction de la Météorologie National ;

- TGBV : Taux Général de Bais Vitrées ;

- ACH: Air Change per Hour (dimensionless);

- K1: constant coefficient of infiltration $(1 / \mathrm{hr})$;

- K2: Temperature coefficient of infiltration $\left(\mathrm{ACH} /{ }^{\circ} \mathrm{C}\right)$;

- K3: Wind Speed coefficient of infiltration (ACH.s/m);

- WS: Wind Speed $(\mathrm{m} / \mathrm{s})$;

- T: Temperature $\left({ }^{\circ} \mathrm{C}\right)$.

\section{Region climate and building description}

\subsection{Region Climate}

El-Ksar El Kebir is a city in northwest of Morocco with 126,523 inhabitants[7], about $160 \mathrm{~km}$ from Rabat, $32 \mathrm{~km}$ from Larache and $110 \mathrm{~km}$ from Tangier.

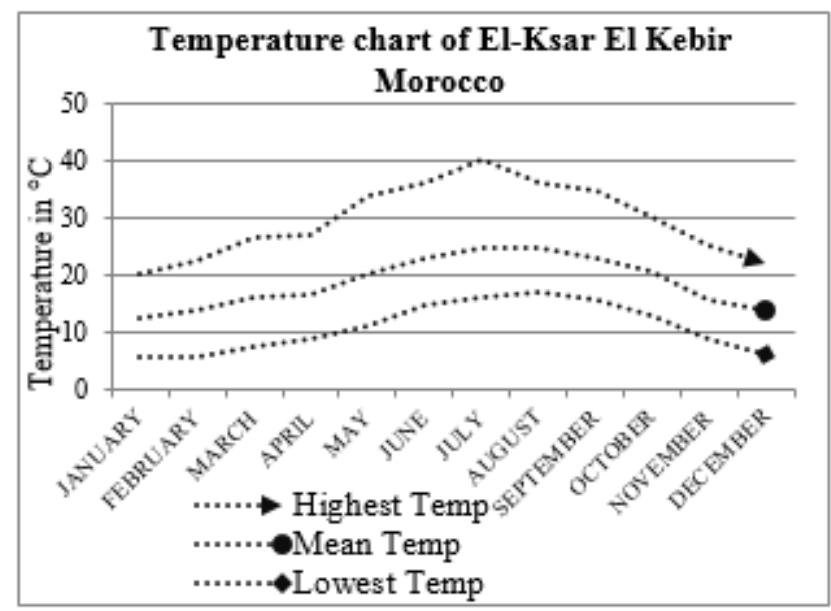

Fig.1. Temperature chart of El-Ksar El Kebir Morocco

The climate of the region is Mediterranean with a peak of temperature reaching $40^{\circ} \mathrm{C}$ during July as shown in the figure 1 . The lowest temperature is recorded during January with a value of $5^{\circ} \mathrm{C}$. The region is also known by its variation in wind speed with a mean value of $16 \mathrm{Km} / \mathrm{h}$ and $148 \mathrm{Km} / \mathrm{h}$ as maximum.

According to the RTCM, El-Ksar EL Kebir is located in the second thermal zone. The climate zoning work of Morocco was carried out in close coordination between the DMN (The National Meteorology Directorate) and ADEREE (National Agency for the Development of Renewable Energy and Energy Efficiency), with the support of international expertise. Moroccan territory was divided into six homogeneous climatic zones based on the analysis of climate data recorded by 37 meteorological stations over the period 1999-2008 (10 years) [1].

\subsection{Thermal zones of RTCM}

Two zoning types were established by the DMN:

- Heating degree-day, base $18^{\circ} \mathrm{C}$.

- Cooling degree-day, base $21^{\circ} \mathrm{C}$.

In this paper we present the cooling and heating degree-day chart of El-Ksar El-Kebir (Figure 2) based on the analysis of climate data, taken from Meteonorm [7], of this region. The heating degree-day in El-Ksar El Kebir reaches 157.59 in January as a peak value, whereas the cooling degree-days reach 113.07 in August.

The figure 2 shows that the total amount of heating's degree-day is 591, while the total of cooling's degree-day is 402; thus buildings in El-Ksar EL-Kebir require more energy for heating than cooling.

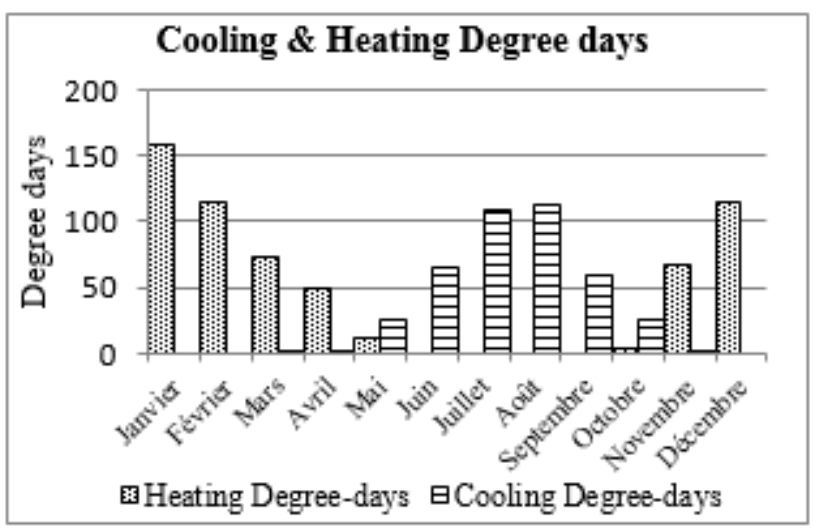

Fig.2. Cooling \& heating Degree Days of El-Ksar El Kebir

\subsection{Building description:}

This analysis concerns a municipal building in the city of El-Ksar El Kebir with a built area of $186.86 \mathrm{~m}^{2}$, and consists of two levels; the effective area of both levels is $266.16 \mathrm{~m}^{2}$, divided into several offices. The main façade is oriented south. Glass panels surface represent $15 \%$ of the external façades, which leads to the perspective approach as described in the RTCM. 
The following figures $(3,4)$ show the space allocation of the two levels.

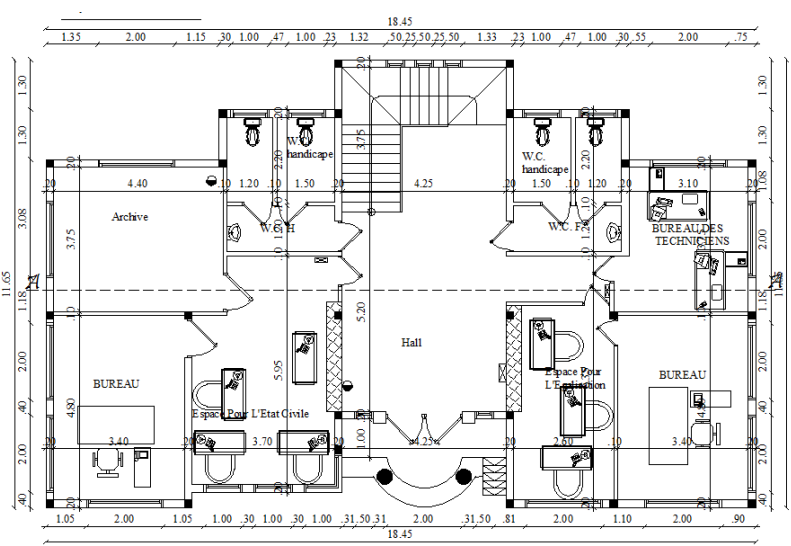

Fig.3. Ground Floor

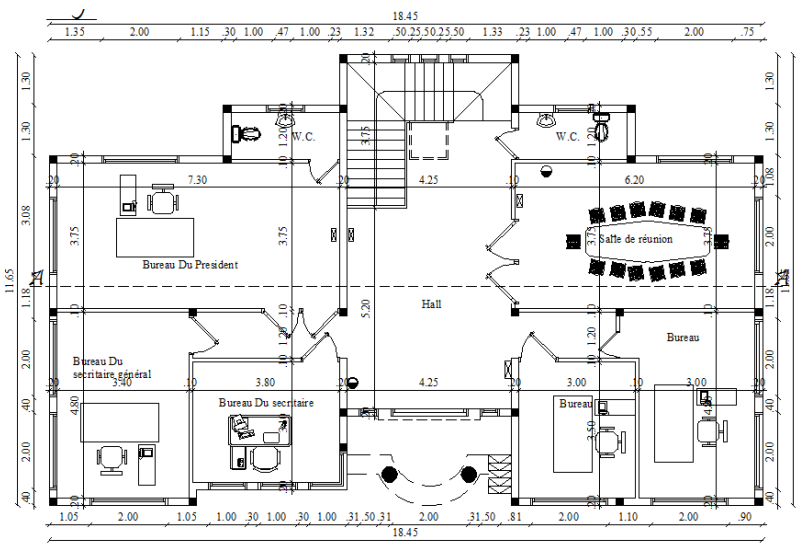

Fig.4. Second floor

Spatial delimitation of the building is presented in table 1 which presents the scenarios adopted for the communal building's occupation. Spaces are named respectively to the occupying functions. Knowing that the working hours of the administrators is limited between $8 \mathrm{am}$ and $4 \mathrm{pm}$ for 5 days, eliminating weekends and holidays. The set point temperature is $18{ }^{\circ} \mathrm{C}$ in winter and $21^{\circ} \mathrm{C}$ in summer.

Table1: Building offices and occupation scenario (part 1)

\begin{tabular}{|c|c|c|c|c|}
\hline & workrooms & Workday/week & Duration & $\begin{array}{c}\text { Set Temp } \\
\text { (Cooling/heating) } \\
{ }^{\circ} \mathrm{C}\end{array}$ \\
\hline \multirow{5}{*}{ Bureau 1 } & 5 days & $08 \mathrm{~h} \rightarrow 16 \mathrm{~h}$ & $21 / 18$ \\
\hline Etat Civil & 5 days & $08 \mathrm{~h} \rightarrow 16 \mathrm{~h}$ & $21 / 18$ \\
\hline Archive & 5 days & $08 \mathrm{~h} \rightarrow 16 \mathrm{~h}$ & $21 / 18$ \\
\hline Hall & 5 days & $08 \mathrm{~h} \rightarrow 16 \mathrm{~h}$ & $21 / 18$ \\
\hline \multirow{2}{*}{$\begin{array}{c}\text { Bureau } \\
\text { Techniciens }\end{array}$} & 5 days & $08 \mathrm{~h} \rightarrow 16 \mathrm{~h}$ & $21 / 18$ \\
\hline Bureau 2 & 5 days & $08 \mathrm{~h} \rightarrow 16 \mathrm{~h}$ & $21 / 18$ \\
\cline { 2 - 5 } & Egalisation & 5 days & $08 \mathrm{~h} \rightarrow 16 \mathrm{~h}$ & $21 / 18$ \\
\hline WC H & 5 days & $08 \mathrm{~h} \rightarrow 16 \mathrm{~h}$ & $\#$ \\
\hline & WC F & 5 days & $08 \mathrm{~h} \rightarrow 16 \mathrm{~h}$ & $\#$ \\
\hline Escalier & 5 days & $08 \mathrm{~h} \rightarrow 16 \mathrm{~h}$ & $21 / 18$ \\
\hline
\end{tabular}

Table1: Building offices and occupation scenario (Part 2)

\begin{tabular}{|c|c|c|c|c|}
\hline \multirow{4}{*}{} & workrooms & $\begin{array}{c}\text { Workday/ } \\
\text { week }\end{array}$ & Duration & $\begin{array}{c}\text { Set Temp } \\
(\text { Cooling/h } \\
\text { eating }{ }^{\circ} \mathrm{C}\end{array}$ \\
\hline \multirow{5}{*}{} & Sec-Générale & 5 days & $08 \mathrm{~h} \rightarrow 16 \mathrm{~h}$ & $21 / 18$ \\
\cline { 2 - 5 } & Secretaire & 5 days & $08 \mathrm{~h} \rightarrow 16 \mathrm{~h}$ & $21 / 18$ \\
\cline { 2 - 5 } & President & 5 days & $08 \mathrm{~h} \rightarrow 16 \mathrm{~h}$ & $21 / 18$ \\
\cline { 2 - 5 } & Hall & 5 days & $08 \mathrm{~h} \rightarrow 16 \mathrm{~h}$ & $21 / 18$ \\
\cline { 2 - 5 } & Salle Réunion & 2 days & $08 \mathrm{~h} \rightarrow 20 \mathrm{~h}$ & $21 / 18$ \\
\cline { 2 - 5 } & Bureau 3 & 5 days & $08 \mathrm{~h} \rightarrow 16 \mathrm{~h}$ & $21 / 18$ \\
\cline { 2 - 5 } & Bureau 4 & 5 days & $08 \mathrm{~h} \rightarrow 16 \mathrm{~h}$ & $21 / 18$ \\
\cline { 2 - 5 } & WC President & 5 days & $08 \mathrm{~h} \rightarrow 16 \mathrm{~h}$ & $\#$ \\
\cline { 2 - 5 } & WC Réunion & 5 days & $08 \mathrm{~h} \rightarrow 16 \mathrm{~h}$ & $\#$ \\
\cline { 2 - 5 } & Escalier & 5 days & $08 \mathrm{~h} \rightarrow 16 \mathrm{~h}$ & $21 / 18$ \\
\hline
\end{tabular}

The compositions of the structural element from outside to inside and their properties are given as [8]:

- Ewternal Wall: $1.5 \mathrm{~cm}$ Cement, $15 \mathrm{~cm}$ brick (12trous), $0.4 \mathrm{~cm}$ blade of air, $6.5 \mathrm{~cm}$ brick (8trous), $1.5 \mathrm{~cm}$ cement;

- Exposed roof: $2 \mathrm{~cm}$ Terracotta tiles, $2 \mathrm{~cm}$ tightness, 8/12 Insulation, 5 Shape, $16 \mathrm{~cm}$ hollow slab, $1.5 \mathrm{~cm}$ cement;

- Intermediate roof: $2 \mathrm{~cm}$ Terracotta tiles, 5 Shape, $16 \mathrm{~cm}$ hollow slab, $1.5 \mathrm{~cm}$ cement;

- Low floor: $2 \mathrm{~cm}$ Terracotta tiles, $5 \mathrm{~cm}$ Shape, $10 \mathrm{~cm}$ Rocks, $2 \mathrm{~cm}$ cement, $0.2 \mathrm{~cm}$ Vapor barrier;

- Internal Wall: $1.5 \mathrm{~cm}$ Cement, $15 \mathrm{~cm}$ brick (12trous), 1.5 cm cement;

\section{Thermal simulation procedures:}

The work was carried out in the simulation studio of TRNSYS, which is a complete simulation package containing several tools, from simulation engine programs and graphical connection programs to plotting and spreadsheet software. It is an integrated tool which can be used from the design of a project to its simulation [9].

In this paper, two important parameters were handled carefully as following:

- The effect of shading devices on the total radiation received on a glazed surface. The overhang and wingwalls play an important role in shading windows and reducing the solar radiation. In order to model these phenomena in TRNSYS we used the TYPE 34 (Overhang and Wingwall shading). Buildings directly heated radiation often include a shading device to shield receiver surfaces from direct radiation in summer months.

This component computes the solar radiation on a vertical receiver shaded by an overhang and/or Wingwall [10]. 
- Infiltration has an important effect on the balance heat transfer. A semi empirical approximation can be used in TRNSYS to compute the influence of infiltration on the cooling and heating balance. Thermal Energy System Specialists TESS implemented a TRNSYS type called TYPE 571 (Humidity ratio input), which uses a semi empirical model recommended by the ASHRAE for the calculation of infiltration to a conditioned zone [11]. The correlation is shown in equation 1.

$$
A C H=K_{1}+K_{2} *\left(T_{\text {zone }}-T_{\text {ambient }}\right)+K_{3} * W S
$$

Suggested values for K1, K2, K3 taken from the ASHRAE Handbook of Fundamentals 1989 are provided below in Table 2 for varying levels of construction.

Table 2: Values for K1, K2, K3

\begin{tabular}{|c|c|c|c|l|}
\hline Construction & $\mathbf{K}_{\mathbf{1}}$ & $\mathbf{K}_{\mathbf{2}}$ & $\mathbf{K}_{\mathbf{3}}$ & \multicolumn{1}{|c|}{ Description } \\
\cline { 2 - 5 } Tight & 0.1 & 0.011 & 0.034 & $\begin{array}{l}\text { New building in } \\
\text { which special } \\
\text { precautions have } \\
\text { been taken to } \\
\text { prevent } \\
\text { infiltration. }\end{array}$ \\
\hline Medium & 0.1 & 0.017 & 0.049 & $\begin{array}{l}\text { Building } \\
\text { constructed using } \\
\text { conventional } \\
\text { construction } \\
\text { procedures. }\end{array}$ \\
\hline Loose & 0.1 & 0.023 & 0.070 & $\begin{array}{l}\text { Evidence of poor } \\
\text { construction on } \\
\text { older buildings } \\
\text { where joints have } \\
\text { separated. }\end{array}$ \\
\hline
\end{tabular}

\section{Results and discussion}

\subsection{Result of simulation without insulation:}

Table 3 presents the simulation results in the case 0 , where the building is in a normal state without any intervention, these results show that the annual heating needs is $10.68 \mathrm{kWh} / \mathrm{m}^{2} /$ year, and $130.91 \mathrm{kWh} / \mathrm{m}^{2} /$ year for cooling.

Table 3: Results of the simulation in the case 0 , with a monthly demand of heating and cooling.

\begin{tabular}{|c|c|c|c|c|}
\hline MONTH & $\begin{array}{c}\text { HEATING } \\
\text { DEMAND } \\
(\mathbf{k W h})\end{array}$ & $\begin{array}{c}\text { HEATING } \\
\text { RATIO } \\
\left(\mathbf{k W h} / \mathbf{M}^{2} / \mathbf{Y}\right)\end{array}$ & $\begin{array}{c}\text { COOLING } \\
\text { DEMAND } \\
(\mathbf{k W h})\end{array}$ & $\begin{array}{c}\text { COOLING } \\
\text { RATIO } \\
\left(\mathbf{k W h} / \mathbf{M}^{2} / \mathbf{Y}\right)\end{array}$ \\
\hline CASE 0 & 2842.34 & 10.68 & 34842.42 & 130.91 \\
\hline
\end{tabular}

According to the RTCM, it is not required to make a performance-based approach, since the building TGBV (General rate of glass panels in percentage, which is the total surface of glass panels by the total surface of external facades) doesn't exceed $45 \%$ it is not mandatory to use the performance approach, so we use the perspective approach that requires this conditions cited hereafter:
- The U of the exposed roof: $\leq 0.65 \mathrm{~W} / \mathrm{m}^{2} . \mathrm{K}$ instead of the initial value $3.72 \mathrm{~W} / \mathrm{m}^{2} . \mathrm{K}$ (Not Conform);

- The external walls $\mathrm{U}: \leq 0.8 \mathrm{~W} / \mathrm{m}^{2} . \mathrm{K}$ instead of the initial value $0.59 \mathrm{~W} / \mathrm{m}^{2} . \mathrm{K}$ (Conform);

- The $\mathrm{U}$ of glazing: $\leq 5.8 \mathrm{~W} / \mathrm{m}^{2} . \mathrm{K}$ instead of the initial value $5.74 \mathrm{~W} / \mathrm{m}^{2} . \mathrm{K}$ (Conform);

- The SHGC (solar heat gain coefficient): NA.

\subsection{Optimization of energy balance:}

In view to reduce the energy bill of the building and to meet the requirement values of RTCM, 9 cases have been proposed:

- Case 1: exposed roof insulation with $4 \mathrm{~cm}$ of extruded polystyrene;

- Case 2: exposed roof insulation with extruded polystyrene $8 \mathrm{~cm}$;

- Case 3: exposed roof insulation with extruded polystyrene $8 \mathrm{~cm}, 10 \mathrm{~cm}$ overhang;

- Case 4: exposed roof insulation with extruded polystyrene $8 \mathrm{~cm}, 20 \mathrm{~cm}$ overhang;

- Case 5: insulation of the exposed roof with Extruded polystyrene $8 \mathrm{~cm}, 30 \mathrm{~cm}$ overhang;

- Case 6: insulation of the exposed roof with Extruded polystyrene $8 \mathrm{~cm}, 60 \mathrm{~cm}$ overhang;

- Case 7: insulation of the exposed roof with Extruded polystyrene $8 \mathrm{~cm}, 80 \mathrm{~cm}$ overhang, and $10 \mathrm{~cm}$ Wingwall; - Case 8: insulation of the exposed roof with Extruded polystyrene $8 \mathrm{~cm}, 10 \mathrm{~cm}$ of overhang, and $10 \mathrm{~cm}$ of Wingwall with TGBV reduced to $10 \%$.

- Case 9: insulation of the exposed roof with Extruded polystyrene $12 \mathrm{~cm}, 10 \mathrm{~cm}$ of overhang, and $10 \mathrm{~cm}$ of Wingwall with TGBV reduced to $10 \%$.

Figure 5 shows the ratio of the energy required for heating and cooling, in different cases.

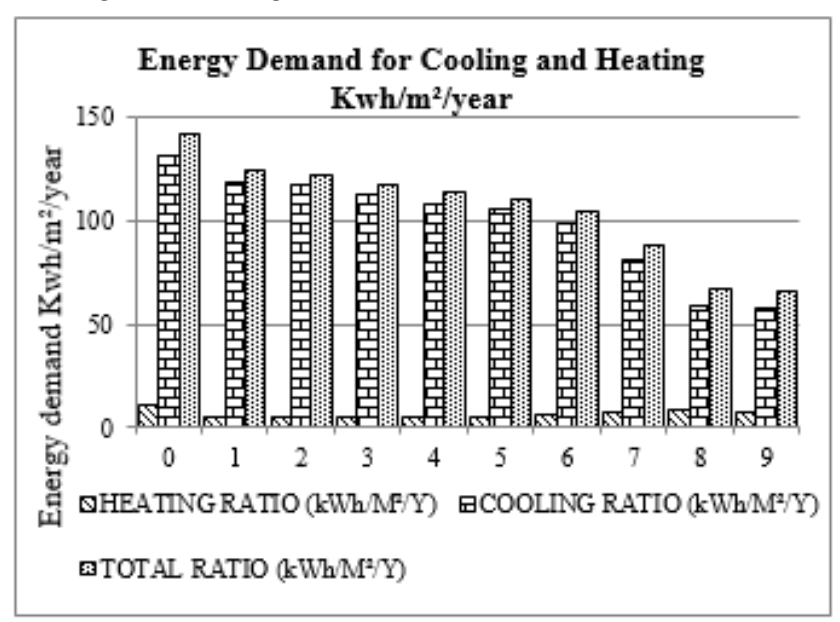

Fig.5. Energetic demand for heating and cooling.

Two variants have given the best technical-economic results for the El-Ksar El Kebir region, which are: 
- Variant 8: Insulation of the roof Exposed with $8 \mathrm{~cm}$ extruded polyethylene, $10 \mathrm{~cm}$ of advanced cap and $10 \mathrm{~cm}$ of the lateral forward.

- Variant 9: Insulation of the roof Exposed with $12 \mathrm{~cm}$ extruded polyethylene, $10 \mathrm{~cm}$ forward of the cap and 10 $\mathrm{cm}$ of the lateral forward.

Table 4: Results of the simulation of the adopted cases, with the total ratio of demand in $\left(\mathrm{Kwh} / \mathrm{m}^{2} / \mathrm{Y}\right)$.

\begin{tabular}{|c|c|c|c|c|c|}
\hline $\begin{array}{c}\text { EL KSAR EL } \\
\text { KEBIR 1 }\end{array}$ & $\begin{array}{c}\text { Hating } \\
\text { demande } \\
(\mathrm{kWh})\end{array}$ & $\begin{array}{c}\text { Hating } \\
\text { ratio } \\
(\mathrm{kWh} / \\
\left.\mathrm{M}^{2} / \mathrm{Y}\right)\end{array}$ & $\begin{array}{c}\text { Cooling } \\
\text { Demande } \\
(\mathrm{kWh})\end{array}$ & $\begin{array}{c}\text { Coolin } \\
\mathrm{g} \text { ratio } \\
\mathrm{kWh} / \\
\left.\mathrm{M}^{2} / \mathrm{Y}\right)\end{array}$ & $\begin{array}{c}\text { Total } \\
\text { ratio } \\
(\mathrm{kWh} / \\
\left.\mathrm{M}^{2} / \mathrm{Y}\right)\end{array}$ \\
\hline $\begin{array}{c}\text { VARIANTE } \\
0\end{array}$ & 2842.34 & 10.68 & 34842.42 & 130.91 & $\mathbf{1 4 1 . 5 9}$ \\
\hline $\begin{array}{c}\text { VARIANTE } \\
8\end{array}$ & 1915.48 & 7.20 & 14806.84 & 55.63 & $\mathbf{6 2 . 8 3}$ \\
\hline $\begin{array}{c}\text { VARIANTE } \\
9\end{array}$ & 1890.49 & 7.10 & 14710.29 & 55.27 & $\mathbf{6 2 . 3 7}$ \\
\hline
\end{tabular}

These two variants tightening duplicate for the other 5 zones, namely (Zone 2: Agadir, Zone 3: Fes, Zone 4: Ifrane, Zone 5: Marrakech, Zone 6: Er-rachidia), to determine the feasibility of this economic building In these thermal zones.

The results obtained for the five other zones using the same variants are shown in the following figure:

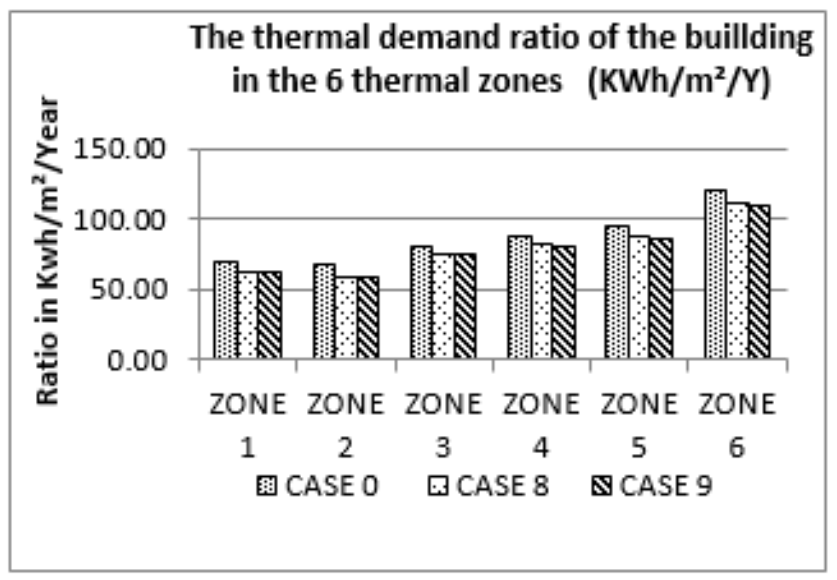

Fig.6. The thermal demand ratio of the building in the 6 thermal zones.

\subsection{Discussion}

The results obtained by the simulation of the building without intervention, and with a glazing rate of $15 \%$ (the initial state according to the architect), shows that the ratio of the heating demand is $10.68 \mathrm{Kwh} / \mathrm{m}^{2} /$ Year, and $130.91 \mathrm{Kwh} / \mathrm{m}^{2} /$ year for cooling ones, thus a total demand of $141.59 \mathrm{Kwh} / \mathrm{m}^{2} /$ year. Table 9 shows the impact of the TGBV reduction on the thermal budget since we have a $50 \%$ reduction in energy demand, whereas the application of roof insulation combined with the overhangs allows a reduction of $55 \%$ since the total ratio reaches $62.37 \mathrm{Kwh} / \mathrm{m}^{2}$ / year, equivalent to an energy bill of 7018
Dhs / year. The previous figure is the subject of the integration of this typical building in the other five zones. The results obtained for Agadir are the best with the lowest demand $59 \mathrm{Kwh} / \mathrm{m}^{2}$ / year, cost the expensive monk of 6475 Dhs / year, Fes also represents conditions that can admit this building since the energy demand of that 74.5 $\mathrm{Kwh} / \mathrm{m}^{2}$ / year equivalent to an annual invoice of 9100 Dhs / year, but for the last three zones (Ifran, Marrakech and Er-rachidia) can not admit this building since it consumes more energy this year. Which pushes to seek other suitable solutions for this type of climate.

Although the building envelope complies with the Moroccan Building Regulation, the building consumes more energy in extremely cold, extremely hot areas.

\section{Conclusion:}

In this work, we have established a parametric study of thermal simulation of building office during summer and winter. In order to minimize the consumption, we proposed 9 variants. The final solution has achieved the objectives. A reduction in the annual bill of energy was obtained amounting to $6887 \mathrm{kWh}$ per year, with 8264 MAD/year of benefices. The main conclusion of this work is that the insulation of the exposed roof allows a significant reduction in the total energy demand, and that this communal building can be the subject of a standardized structure for the 3 zones, Tangier, Agadir and Fes, in view of the energy performance that it showed, specifically for Agadir, in order to apply to the requirements of the RTCM on the one hand and to follow the global approach to fight against global warming.

\section{References:}

1. RTCM, Règlement Thermique de Construction au Maroc (2014)

2. The GEF CEO Endorsement Request - PIMS 3230 Morocco EE Building Code4, (May 1, 2009)

3. Rapport des activités annuelles 2014 ONE

4. Hassan Bouhess, Hassan Hamdi, Brahim Benhamou, Amin Bennouna, Pierre Hollmuller And Karim Limam, dynamic simulation of an earth-to-air heat exchanger connected to a villa type house in marrakech; Proceedings Of BS2013:13th Conference Of International Building Performance Simulation Association, Chambéry, France, August 26-28 (2013)

5. Bulletin officiel du Maroc 6360

6. Haut Commissariat au Plan RGPH (2014)

7. Meteonorm Global Meteorological databas Version 7

8. Bibliothèque BINAYAT perspective 2014

9. TRNSYS Manuel: Volume 6, Multizone modeling with TYPE 56 and TRNBuild

10. Mathematical reference of TRNSYS 16, 5.7.4. Type 34: Overhang and Wingwall Shading

11. ASHRAE Handbook of Fundamentals (1989), chapter 22: Ventilation and Infiltration 
12. N. Fezzioui, B. Droui, M. Benyamine, et S. Larbi, Influence des caractéristiques dynamiques de l'enveloppe d'un bâtiment sur le confort thermique au sud Algérien, Revue des Energies Renouvelables Vol. $11 \mathrm{~N}^{\circ} 1$ (2008) 25 - 34. 